\title{
Polyphyllin VII induces apoptotic cell death via inhibition of the PI3K/Akt and NF-кB pathways in A549 human lung cancer cells
}

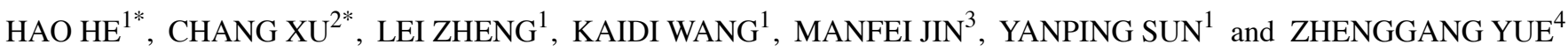 \\ ${ }^{1}$ School of Pharmacy, Xi'an Medical University, Xi'an, Shaanxi 710021; ${ }^{2}$ National Vaccine and \\ Serum Institute, Beijing 100176; ${ }^{3}$ School of Public Health, Xi'an Medical University, Xi'an, Shaanxi 710021; \\ ${ }^{4}$ Shaanxi Collaborative Innovation Center of Chinese Medicinal Resource Industrialization, School of Pharmacy, \\ Shaanxi University of Traditional Chinese Medicine, Xianyang, Shaanxi 712046, P.R. China
}

Received December 3, 2018; Accepted October 10, 2019

DOI: $10.3892 / \mathrm{mmr} .2019 .10879$

\begin{abstract}
Polyphyllin VII is an active compound isolated from Paris polyphylla, which is termed Chonglou in China. The present study was designed to investigate the underlying mechanisms of the antitumor effect of Polyphyllin VII in lung cancer cells. The cytotoxic effect of Polyphyllin VII in human lung cancer A549 cells was analyzed; the results revealed an $\mathrm{IC}_{50}$ value of $0.41 \pm 0.10 \mu \mathrm{M}$ at $24 \mathrm{~h}$. The associated mechanisms were investigated by phase-contrast microscopy, fluorescence microscopy, flow cytometry and western blot analysis. Exposure of A549 cells to Polyphyllin VII resulted in apoptosis. Pyrrolidine dithiocarbamate (PDTC), an inhibitor of NF- $\mathrm{NB}$, and wortmannin, an inhibitor of PI3K, both decreased the proportion of viable A549 cells in the presence of Polyphyllin VII. The ratio of apoptotic cells increased in the presence of wortmannin and PDTC. Western blot analysis revealed that PI3K, phosphorylated (p)-PI3K, Akt, p-Akt, NF- $\kappa \mathrm{B}$ and $\mathrm{p}-\mathrm{NF}-\kappa \mathrm{B}$ were downregulated following treatment with Polyphyllin VII. Increased caspase-3 activity, increased poly-(ADP-ribose) polymerase cleavage and a downregulation of inhibitor of caspase-activated DNase were observed following treatment with Polyphyllin VII, and these effects were enhanced by either wortmannin or PDTC. The present results revealed that Polyphyllin VII was able to induce apoptotic cell death in A549 human lung cancer cells via inhibition of the PI3K/Akt and NF- $\mathrm{KB}$ pathways.
\end{abstract}

\section{Introduction}

Lung cancer is the biggest cause of cancer-associated mortality in men and is the second biggest cause of cancer-associated mortality in women worldwide (1). In the USA, there were

Correspondence to: Dr Hao He, School of Pharmacy, Xi'an Medical University, 1 Xin Wang Road, Xi'an, Shaanxi 710021, P.R. China

E-mail: hehao313@163.com

${ }^{*}$ Contributed equally

Keywords: polyphyllin VII, lung cancer, apoptosis, $\mathrm{PI} 3 \mathrm{~K}, \mathrm{Akt}, \mathrm{NF}-\kappa \mathrm{B}$ $\sim 121,680$ new cases of lung cancer in men and $\sim 112,350$ in women in 2018 (2). There are two main histological types of lung cancer: Non-small cell lung cancer (NSCLC) and small cell lung cancer (SCLC). Overall, 85-90\% of all lung cancer cases are NSCLC (3). The 5-year survival rate of NSCLC is $55 \%$ at an initial stage; however, this reduces to $<4 \%$ with distant metastasis (2). Therefore, it is necessary to characterize the mechanisms involved in NSCLC progression.

$\mathrm{NF}-\kappa \mathrm{B}$ is a pro-inflammatory transcription factor, which binds with the inhibitory molecule nuclear factor of $\kappa$ light polypeptide gene enhancer in $\mathrm{B}$ cells inhibitor $(\mathrm{I} \kappa \mathrm{B}) \mathrm{a}$ in the majority of cells. NF- $\kappa \mathrm{B}$ can be activated by stimulating factors, including carcinogens and inflammatory proteins, which results in I $\mathrm{B}$ Ba phosphorylation and degradation, leading to the release and nuclear translocation of NF- $\kappa \mathrm{B}$ dimers (4). Subsequently, the activated $\mathrm{NF}-\kappa \mathrm{B}$ promotes tumor cell division, proliferation, angiogenesis and metastasis, and also prevents tumor cell apoptosis, which leads to the development of carcinomas (5). Therefore, activated NF- $\kappa \mathrm{B}$ should suppressed in cancer treatment. The PI3K/Akt pathway serves a key role in carcinogenesis and has been identified as constitutively activated in different types of human cancer (6). The PI3K/Akt cell survival pathway also plays a key role in the regulation of apoptotic cell death via NF- $\kappa$ B.

Natural products with potential anticancer effects are an important source for the identification of novel therapeutic drugs (7). As a traditional Chinese medicine with heat-clearing and detoxicating functions $(8,9)$, Paris polyphylla (Chonglou in Chinese) is a medicinal herb listed in the pharmacopoeia in China (10), which has been used for the treatment of inflammation and cancer, particularly lung cancer. Polyphyllin VII is an active steroid saponin isolated from P. polyphylla (11).

The present study was designed to investigate the cell growth inhibitory effects of Polyphyllin VII on A549 cells and the mechanisms of Polyphyllin VII-induced apoptotic cell death. The mechanisms involved were investigated by phase-contrast microscopy, fluorescence microscopy, flow cytometry and western blot analysis.

\section{Materials and methods}

Chemicals and reagents. Fetal bovine serum (FBS) and RPMI-1640 medium were obtained from HyClone (GE 
Healthcare Life Sciences). Acridine orange (AO), Hoechst 33258, ammonium pyrrolidinedithiocarbamate (PDTC) and rhodamine 123 were purchased from Sigma-Aldrich (Merck KGaA). Wortmannin was purchased from MedChem Express. Polyclonal antibodies against PI3K (cat. no. 20584-1-AP), Akt (cat. no. 10176-2-AP), NF-кB p65 (cat. no. 10745-1-AP), IкB (cat. no. 10268-1-AP), GAPDH (cat. no. 10494-1-AP), lamin B (cat. no. 12987-1-AP), caspase-3 (cat. no. 19677-1-AP), poly-(ADP-ribose) polymerase (PARP; cat. no. 13371-1-AP) and inhibitor of caspase-activated DNase (ICAD; cat. no. 10191-2-AP) were obtained from ProteinTech Group, Inc. Phosphorylated (p)-PI3K (cat. no. 4228), p-Akt (cat. no. 4060) and p-NF-кB p65 (cat. no. 3033) antibodies were from Cell Signaling Technology, Inc. Horseradish peroxidase (HRP)-conjugated secondary antibodies (whole IgG affinity-purified antibodies, cat. no. 115-035-003) were obtained from Jackson ImmunoResearch Laboratories, Inc. Enhanced chemiluminescence (ECL) western blotting substrate was from Thermo Fisher Scientific, Inc., and the Annexin V-FITC/propidium iodide (PI) staining kit was from 7 Sea Biotech, Inc.

Plant material. Polyphyllin VII was purchased from Chengdu Pufei De Biotech Co., Ltd. (cat. no. 76296-75-8). Polyphyllin VII was dissolved in DMSO and diluted with RPMI-1640 medium (HyClone; GE Healthcare Life Sciences). The DMSO concentration was kept $<0.05 \%$ in all cell cultures and did not exert any detectable effect on cell growth.

Cell culture. Human lung cancer A549 cells were provided by Stem Cell Bank, Chinese Academy of Sciences (batch no. SCSP-503). Cells were cultured in RPMI-1640 medium supplemented with $10 \% \mathrm{FBS}, 100 \mathrm{U} / \mathrm{ml}$ penicillin and $100 \mu \mathrm{g} / \mathrm{ml}$ streptomycin in a humidified atmosphere with 5\% $\mathrm{CO}_{2}$ at $37^{\circ} \mathrm{C}$. Cells in the exponential phase of growth were used in the experiments.

Cell viability assay. A549 cells were seeded in 96-well flat bottom cell culture clusters (Corning, Inc.) with $100 \mu \mathrm{l}$ per well at a density of $6 \times 10^{4}$ cells $/ \mathrm{ml}$. Following culture for $24 \mathrm{~h}$, the cells were treated with increasing concentrations $(0,0.1$, $0.2,0.4,0.8$ and $1.6 \mu \mathrm{M}$ ) of Polyphyllin VII for $24 \mathrm{~h}$ at $37^{\circ} \mathrm{C}$. Alternatively, the cells were treated with $0.41 \mu \mathrm{M}$ Polyphyllin VII in the presence or absence of $2 \mu \mathrm{M}$ wortmannin and $30 \mu \mathrm{M}$ PDTC for $24 \mathrm{~h}$ at $37^{\circ} \mathrm{C}$. Subsequently, the cells were washed twice with ice-cold PBS and incubated with $5 \mathrm{mg} / \mathrm{ml}$ MTT solution at $37^{\circ} \mathrm{C}$ for $4 \mathrm{~h}$. The medium was then removed and $150 \mu \mathrm{l}$ DMSO was added to dissolve the resulting crystals. The optical density was measured using a microplate reader at 492 nm (Multiskan GO; Thermo Fisher Scientific, Inc.). The percentage of cell viability was calculated as follows:

Cell viability $(\%)=\left(\mathrm{A}_{492 \text { sample }}-\mathrm{A}_{492 b \text { bank }}\right) /\left(\mathrm{A}_{492 \text { control }}-\mathrm{A}_{492 b \text { bank }}\right) \times 100$.

Observation of morphological changes and fluorescence microscopy of apoptosis with $A O$ and Hoechst 33258 staining. A549 cells were seeded into 24-well culture plates (Corning, Inc.) at a density of $2 \times 10^{4}$ cells/well with or without Polyphyllin VII $(0.41 \mu \mathrm{M})$ for $24 \mathrm{~h}$ at $37^{\circ} \mathrm{C}$. The cellular morphology changes were observed using a phase-contrast microscope
(Olympus Corporation). Following treatment with Polyphyllin VII, the cells were stained with $20 \mu \mathrm{g} / \mathrm{ml} \mathrm{AO}$ and incubated in the dark for $15 \mathrm{~min}$ at room temperature. For Hoechst 33258 staining, the medium was removed following treatment with Polyphyllin VII for $24 \mathrm{~h}$, the cells were fixed with $0.5 \mathrm{ml}$ $70 \%$ ethanol at $4^{\circ} \mathrm{C}$ for $30 \mathrm{~min}$, then washed twice with PBS and incubated with $0.5 \mathrm{ml} 10 \mu \mathrm{g} / \mathrm{ml}$ Hoechst 33258 solution for $5 \mathrm{~min}$ at room temperature. All changes in fluorescence were observed using an Olympus IX73 inverted fluorescence microscope (Olympus Corporation).

Nuclear protein extracts preparation. A549 cells were treated with $0.41 \mu \mathrm{M}$ Polyphyllin VII under the indicated conditions, then they were harvested and suspended in cold PBS. Following centrifugation at $1,000 \mathrm{x}$ g for $15 \mathrm{~min}$ at $4^{\circ} \mathrm{C}$, the cells were resuspended in lysis buffer A (20 mM HEPES, $10 \mathrm{mM} \mathrm{KCl}, 1.5 \mathrm{mM} \mathrm{MgCl} 2,1 \mathrm{mM}$ EDTA, $1 \mathrm{mM}$ EGTA, $1 \mathrm{mM}$ DTT and $1 \mathrm{mM}$ PMSF) at $4^{\circ} \mathrm{C}$ for $60 \mathrm{~min}$. Following centrifugation at $28,000 \mathrm{x} \mathrm{g}$ for $20 \mathrm{~min}$ at $4^{\circ} \mathrm{C}$, the pellet was resuspended in lysis buffer B (20 mM HEPES, $25 \%$ glycerol, $420 \mathrm{mM} \mathrm{NaCl}, 1.5 \mathrm{mM} \mathrm{MgCl}_{2}, 0.2 \mathrm{mM}$ EDTA, $0.5 \mathrm{mM}$ PMSF, $0.5 \mathrm{mM}$ DTT and $5 \mu \mathrm{g} / \mathrm{ml}$ leupeptin) at $4^{\circ} \mathrm{C}$ for $15 \mathrm{~min}$. Finally, after centrifugation at $16,000 \mathrm{xg}$ for $10 \mathrm{~min}$ at $4^{\circ} \mathrm{C}$, the nuclear proteins were identified in the supernatant.

Western blot analysis. A549 cells were treated with $0.41 \mu \mathrm{M}$ Polyphyllin VII for $0,12,24$, and $48 \mathrm{~h}$, or were treated with Polyphyllin VII in the presence or absence of $2 \mu \mathrm{M}$ wortmannin and $30 \mu \mathrm{M}$ PDTC for $24 \mathrm{~h}$ at $37^{\circ} \mathrm{C}$. Subsequently, the cells were harvested and lysed in RIPA lysis buffer $(50 \mathrm{mM}$ Tris $\mathrm{pH} 7.4,150 \mathrm{mM} \mathrm{NaCl}, 1 \%$ Triton $\mathrm{X}-100,1 \%$ sodium deoxycholate, $0.1 \%$ SDS, $2 \mathrm{mM}$ EDTA and $100 \mathrm{mM}$ sodium fluoride) at $4{ }^{\circ} \mathrm{C}$ for $60 \mathrm{~min}$. Lysates were centrifuged at $12,000 \mathrm{x} \mathrm{g}$ for $15 \mathrm{~min}$ at $4^{\circ} \mathrm{C}$, the supernatant was pipetted and the protein content was determined using a Bio-Rad protein assay (Bio-Rad Laboratories, Inc.). Equal amounts of total protein $(30 \mu \mathrm{g})$ were separated by $12 \%$ SDS-PAGE and then transferred to an Immobilon ${ }^{\circledR}$-P transfer membrane (EMD Millipore). The membrane was then incubated with blocking buffer (5\% skimmed milk in $0.5 \%$ Tween-20) for $2 \mathrm{~h}$ at room temperature. Proteins were detected with primary antibodies against PI3K (1:500), p-PI3K (1:500), Akt (1:500), p-Akt

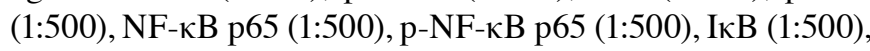
GAPDH (1:500), lamin B (1:500), caspase-3 (1:500), PARP (1:500) and ICAD (1:500), incubated at $4^{\circ} \mathrm{C}$ for $12 \mathrm{~h}$, followed by HRP-conjugated secondary antibody $(1: 20,000)$, incubated at room temperature for $2 \mathrm{~h}$. The proteins were visualized using enhanced chemiluminescence reagent (Thermo Fisher Scientific, Inc.) with Image Lab software (version 5.2.1, Bio-Rad Laboratories, Inc.).

Flow cytometric analysis of apoptosis. Human A549 lung cancer cells were cultured in a $25-\mathrm{cm}^{2}$ culture bottle (Corning Inc.) at a density of $4 \times 10^{5}$ cells/bottle for $24 \mathrm{~h}$. Subsequently, the cells were treated with $0.41 \mu \mathrm{M}$ Polyphyllin VII for $24 \mathrm{~h}$ in the presence or absence of $2 \mu \mathrm{M}$ wortmannin or $30 \mu \mathrm{M}$ PDTC at $37^{\circ} \mathrm{C}$. Thereafter, the cells were harvested using trypsin (without EDTA), and rinsed with PBS. The cells were then stained with Annexin V-FITC/PI using a commercial kit, following the manufacturer's protocol. Finally, cells 
were analyzed using an Accuri C6 FACScan flow cytometer (Becton, Dickinson and Company) with CFlow Plus software (version 1.0.264.15, Accuri Cytometers, Inc.).

Determination of mitochondrial membrane potential. The mitochondrial membrane potential $(\Delta \psi \mathrm{m})$ was examined using the mitochondrial dye rhodamine 123. Following incubation with $0.41 \mu \mathrm{M}$ Polyphyllin VII for $24 \mathrm{~h}$ in the presence or absence of $2 \mu \mathrm{M}$ wortmannin or $30 \mu \mathrm{M}$ PDTC, A549 cells were collected and stained with $1 \mu \mathrm{g} / \mathrm{ml}$ rhodamine 123 at $37^{\circ} \mathrm{C}$ for $30 \mathrm{~min}$. Subsequently, the fluorescence intensity was measured by flow cytometric analysis and the results were analyzed by CFlow Plus software (version 1.0.264.15, Accuri Cytometers, Inc.).

Statistical analysis. All the presented data and results were confirmed in at least three independent experiments and are presented as the mean \pm standard deviation. Statistical comparisons were made by Student's t-test or one-way analysis of variance followed by Tukey's post hoc test. $\mathrm{P}<0.05$ was considered to indicate a statistically significant difference.

\section{Results}

Polyphyllin VII suppresses the viability of human lung cancer A549 cells. A549 cells were cultured with 0, 0.1, 0.2, 0.4 , $0.8,1.6 \mu \mathrm{M}$ Polyphyllin VII for $24 \mathrm{~h}$, and the cell viability was analyzed by MTT assay. Polyphyllin VII decreased the numbers of viable cells in a concentration-dependent manner, with an $\mathrm{IC}_{50}$ value at $24 \mathrm{~h}$ of $0.41 \pm 0.10 \mu \mathrm{M}$ (Fig. 1A). The morphological changes of A549 cells were examined to evaluate the features of the decreased cell viability. The Polyphyllin VII-treated group exhibited membrane blebbing and granular apoptotic bodies (Fig. 1B). Fluorescence microscopy with AO staining also showed granular apoptotic bodies (Fig. 1C), and Hoechst 33258 staining revealed significant nuclear condensation or nuclear fragmentation (Fig. 1D) following Polyphyllin VII treatment. These results indicated that Polyphyllin VII suppressed human lung cancer A549 cell proliferation and that it may have induced apoptosis.

Polyphyllin VII induces apoptotic death in A549 cells. Subsequently, the mechanism of Polyphyllin VII-induced cell inhibition was investigated. A549 cells were pretreated with $2 \mu \mathrm{M}$ wortmannin (a PI3K inhibitor) or $30 \mu \mathrm{M}$ PDTC (a $\mathrm{NF}-\kappa \mathrm{B}$ inhibitor) prior to treatment with Polyphyllin VII. The concentrations of these inhibitors were determined according to previous studies and were screened $(12,13)$. The cell viability of the Polyphyllin VII-treated group was markedly decreased by co-incubation with wortmannin or PDTC (Fig. 2A).

It is understood that the integrity of mitochondrial membranes is associated with apoptotic cell death; therefore, the mitochondrial membrane potential $(\Delta \psi \mathrm{m})$ was detected by flow cytometric analysis following rhodamine 123 staining. Polyphyllin VII-treated A549 cells exhibited a decreased fluorescence intensity due a decrease in $\Delta \psi \mathrm{m}$. In addition, this effect was enhanced by both wortmannin and PDTC combination treatments (Fig. 2B; Table I).

An Annexin V-FITC/PI staining assay was used to further explore the mechanism underlying the Polyphyllin VII-induced
Table I. $\Delta \psi \mathrm{m}$ measurements in A549 cells following treatments.

\begin{tabular}{lc}
\hline Group & $\Delta \psi \mathrm{m}$ \\
\hline Control & $93.30 \pm 2.21$ \\
Polyphyllin VII & $76.60 \pm 3.67$ \\
Polyphyllin VII + Wortmanin & $64.23 \pm 4.15^{\mathrm{a}}$ \\
Polyphyllin VII + PDTC & $49.53 \pm 5.16^{\mathrm{a}}$
\end{tabular}

${ }^{\mathrm{a}} \mathrm{P}<0.01$ vs. Polyphyllin VII-treated group. $\Delta \psi \mathrm{m}$, mitochondrial membrane potential; PDTC, pyrrolidine dithiocarbamate.

Table II. Apoptotic ratios in A549 cells following treatments.

\begin{tabular}{lcc}
\hline Group & $\begin{array}{c}\text { Annexin } \\
\text { V-FITC }^{+} / \mathrm{PI}^{-}\end{array}$ & $\begin{array}{c}\text { Annexin } \\
\mathrm{V}^{-F_{T C C}} / \mathrm{PI}^{+}\end{array}$ \\
\hline Control & $0.50 \pm 0.36$ & $0.10 \pm 0.10$ \\
Polyphyllin VII & $41.20 \pm 2.81$ & $3.70 \pm 1.49$ \\
Polyphyllin VII + Wortmanin & $52.93 \pm 2.70^{\mathrm{a}}$ & $3.03 \pm 1.00$ \\
Polyphyllin VII + PDTC & $61.40 \pm 4.40^{\mathrm{a}}$ & $3.30 \pm 2.09$ \\
\hline
\end{tabular}

${ }^{\text {aP }}<0.01$ vs. Polyphyllin VII-treated group. PDTC, pyrrolidine dithiocarbamate.

inhibition of A549 cells. Flow cytometric analysis revealed a significant increase in the percentage of early apoptotic cells (Annexin V staining only; lower right panels) and late apoptotic cells (Annexin V and PI staining; upper right panels) in the Polyphyllin VII-treated group compared with the control group (Fig. 3; Table II). The ratio of apoptotic cells in the Polyphyllin VII-treated group was further increased following incubation with wortmannin or PDTC (Fig. 3; Table II). In summary, these results demonstrated that Polyphyllin VII induced apoptotic death in A549 cells.

Polyphyllin VII induces apoptotic death via the PI3K/Akt and NF- $\kappa B$ pathways in A549 cells. Wortmannin and PDTC demonstrated the same phenotypic effects when incubated with Polyphyllin VII in A549 cells, suggesting that the $\mathrm{PI} 3 \mathrm{~K} / \mathrm{Akt}$ and NF- $\mathrm{KB}$ pathways may be involved in the role of Polyphyllin VII. The protein expression levels in Polyphyllin VII-treated A549 cells were measured by western blot analysis. The results indicated that Polyphyllin VII treatment induced marked changes in the protein expression of A549

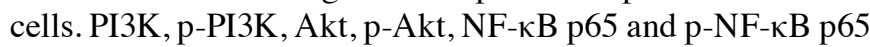
were obviously downregulated, while I $\kappa \mathrm{B}$ was upregulated, in a time-dependent manner in Polyphyllin VII-treated A549 cells (Fig. 4). Of note, there were no significant changes in

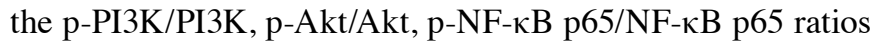
between most of the treatment groups (Fig. 4), suggesting that Polyphyllin VII downregulated the total expression levels of these proteins rather than their phosphorylation. The p-NF- $\mathrm{B}$ p65 levels in the nuclear extract of A549 cells were also downregulated following Polyphyllin VII-treatment (Fig. 4). Furthermore, the effects of Polyphyllin VII on the 


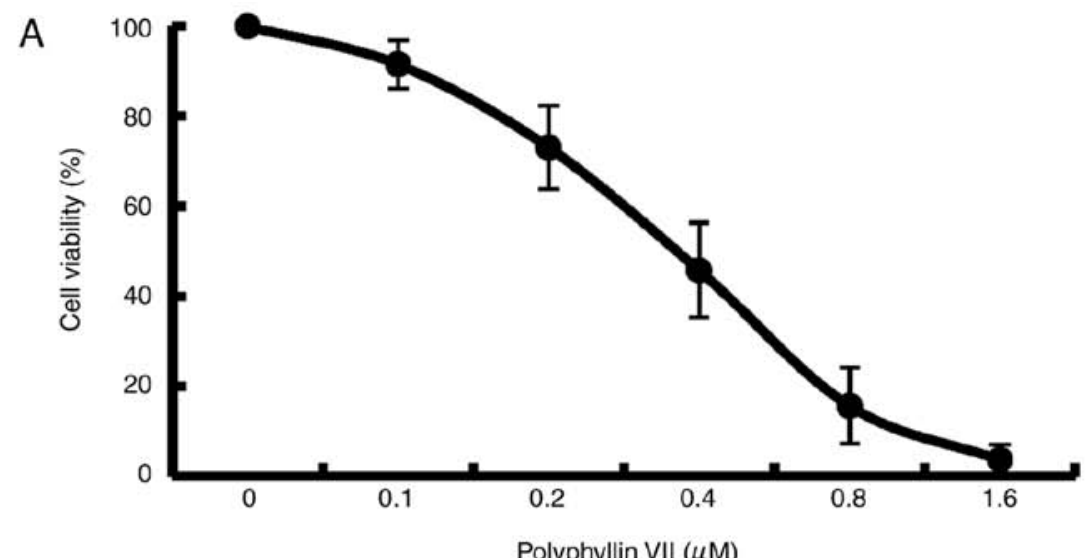

Control

B

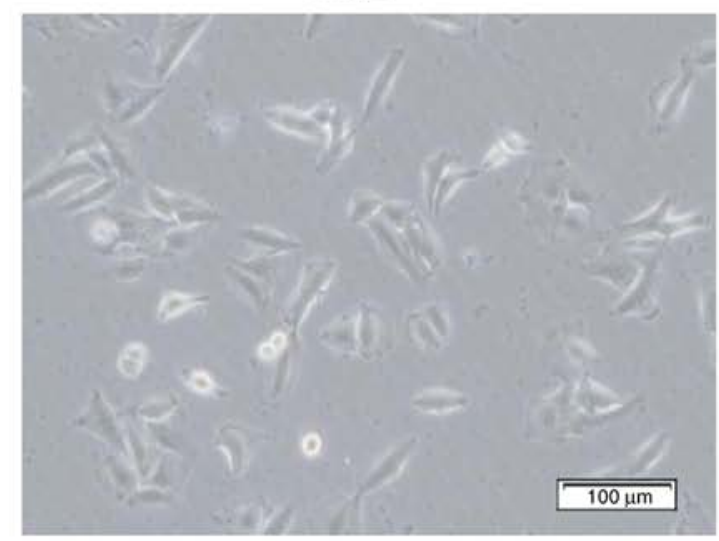

C

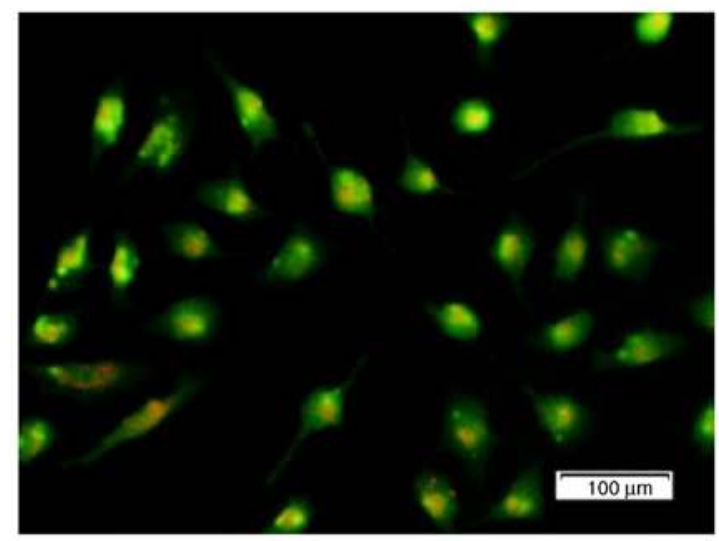

D

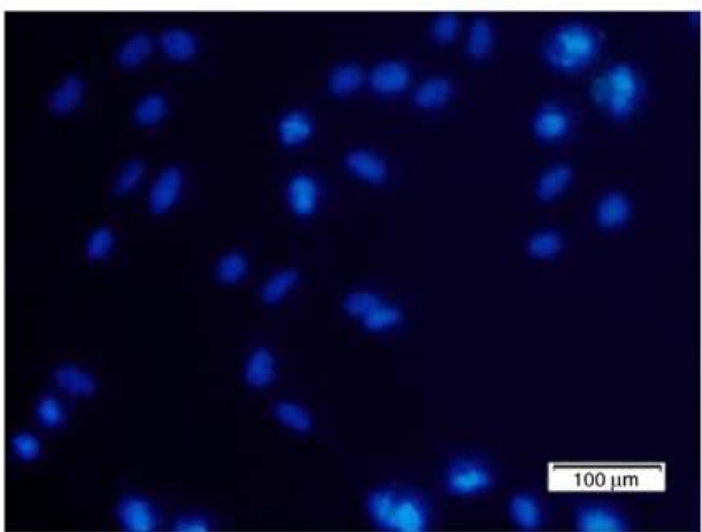

Polyphyllin VII
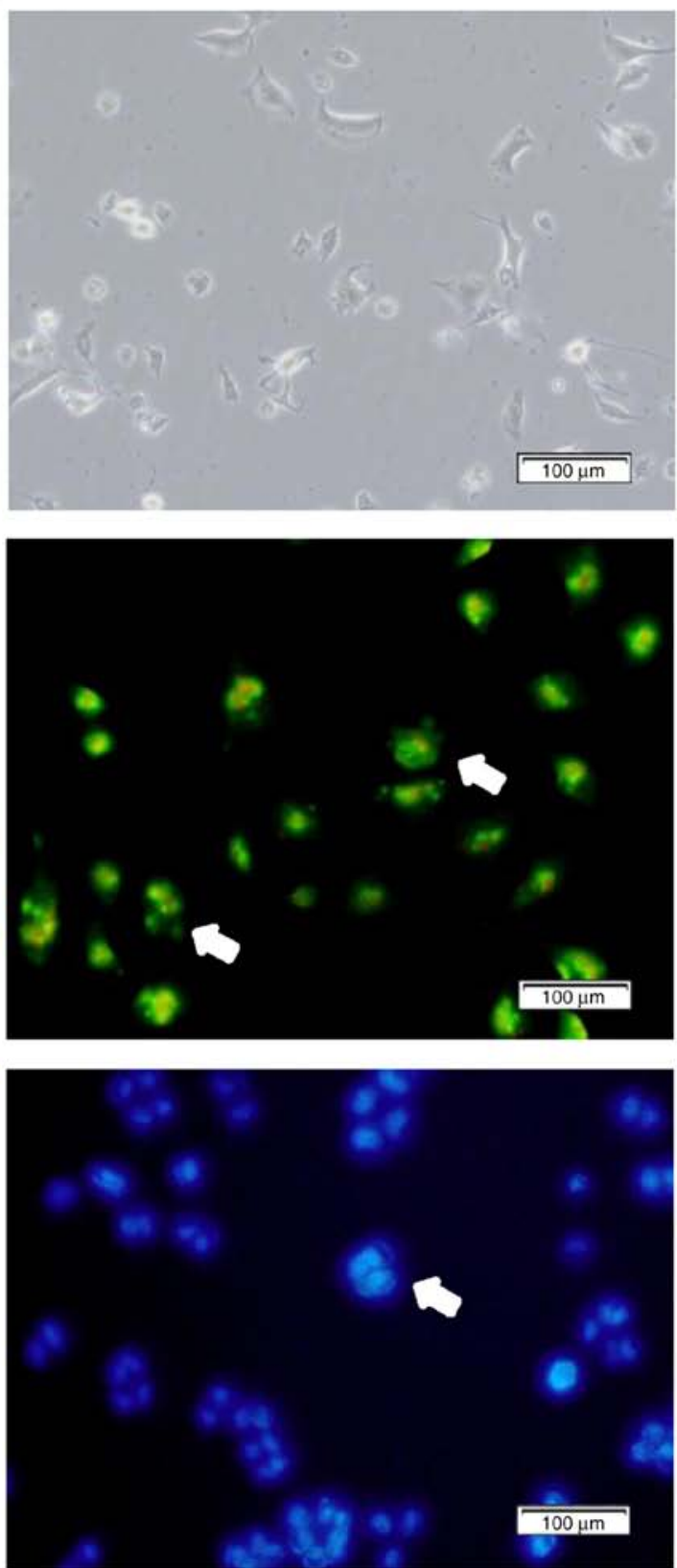

Figure 1. Polyphyllin VII decreases the viability of A549 Cells. (A) Cells were treated with 0, 0.1, 0.2, 0.4, 0.8, 1.6 $\mu$ M Polyphyllin VII for 24 h, and the cell viability was measured by MTT assay (mean \pm standard deviation of 3 independent experiments). (B) A549 cells were incubated with $0.41 \mu$ M Polyphyllin VII for $24 \mathrm{~h}$, and the cellular morphological changes were observed by phase-contrast microscopy (magnification x100; scale bar, $100 \mu \mathrm{m}$ ). (C) Fluorescence microscopy following AO staining (magnification x100; scale bar, $100 \mu \mathrm{m}$ ) or (D) Hoechst 33258 staining (magnification x100; scale bar, $100 \mu \mathrm{m}$ ). Arrows indicate apoptotic bodies in AO staining and DNA condensation in Hoechst 33258 staining. The experiments were performed in triplicate. AO, acridine orange. 
A

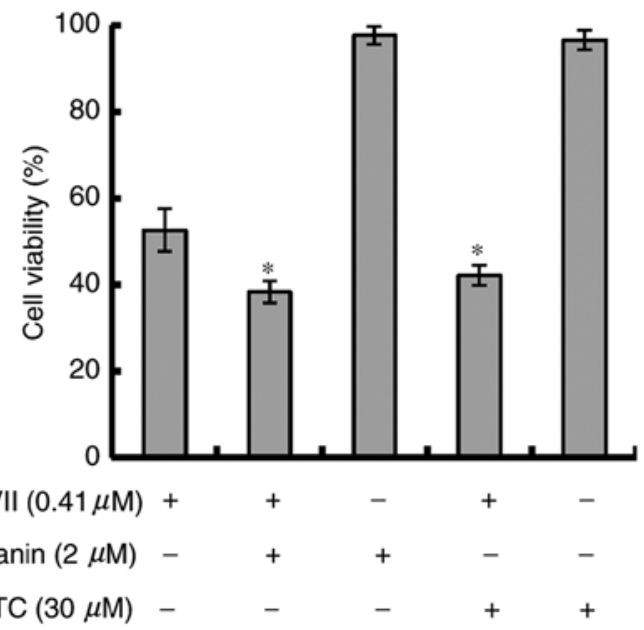

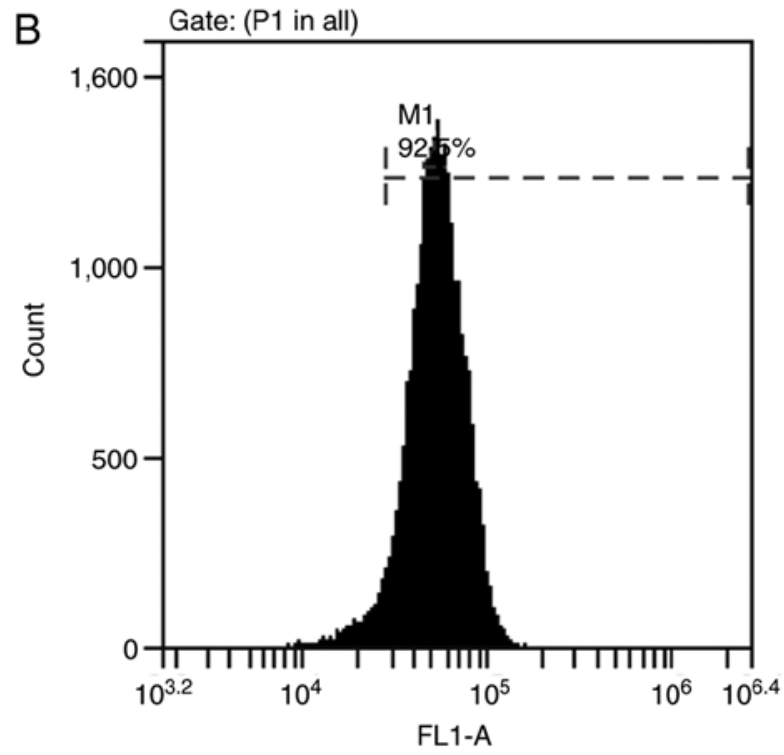

Control

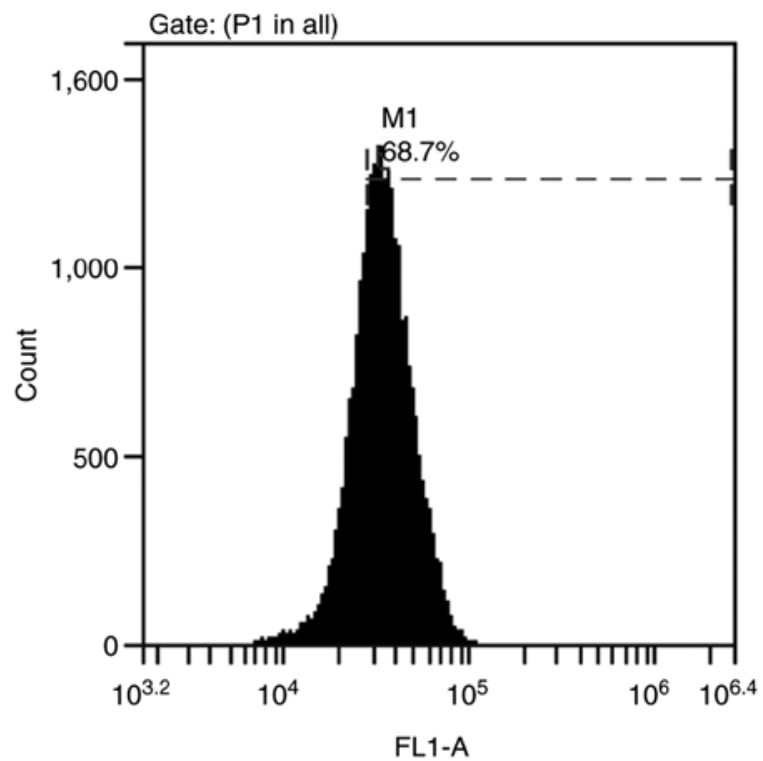

Polyphyllin VII+Wortmanin

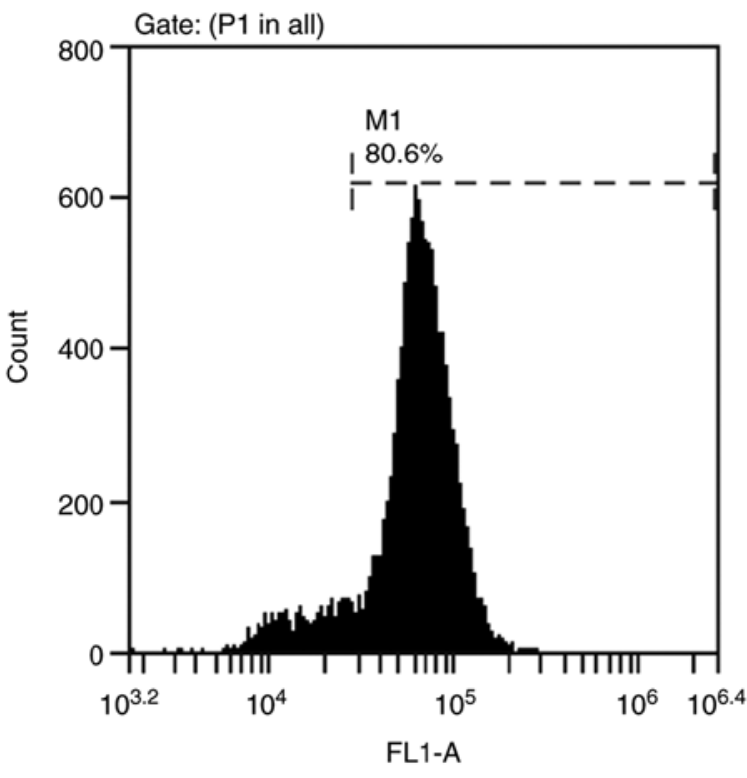

Polyphyllin VII $0.41 \mu \mathrm{M}$

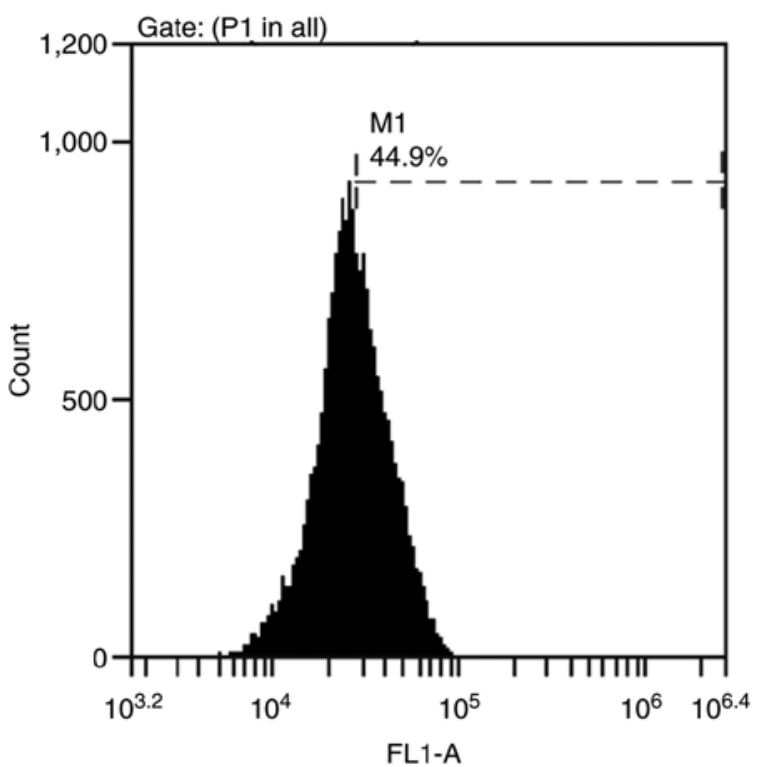

Polyphyllin VII+PDTC

Figure 2. Polyphyllin VII-induced cell viability inhibition is associated with PI3K and NF- $\kappa$ B. A549 cells were cultured with $0.41 \mu$ M Polyphyllin VII in the presence or absence of $2 \mu \mathrm{M}$ wortmannin or $30 \mu \mathrm{M}$ PDTC for $24 \mathrm{~h}$. (A) Cell viability was measured by MTT assay. (B) Cells were loaded with the membrane-sensitive probe rhodamine 123 , and the mitochondrial membrane potential was measured by flow cytometric analysis. Data are presented as mean \pm standard deviation of 3 independent experiments, ${ }^{*} \mathrm{P}<0.05$ vs. Polyphyllin VII-treated group. PDTC, pyrrolidine dithiocarbamate. 


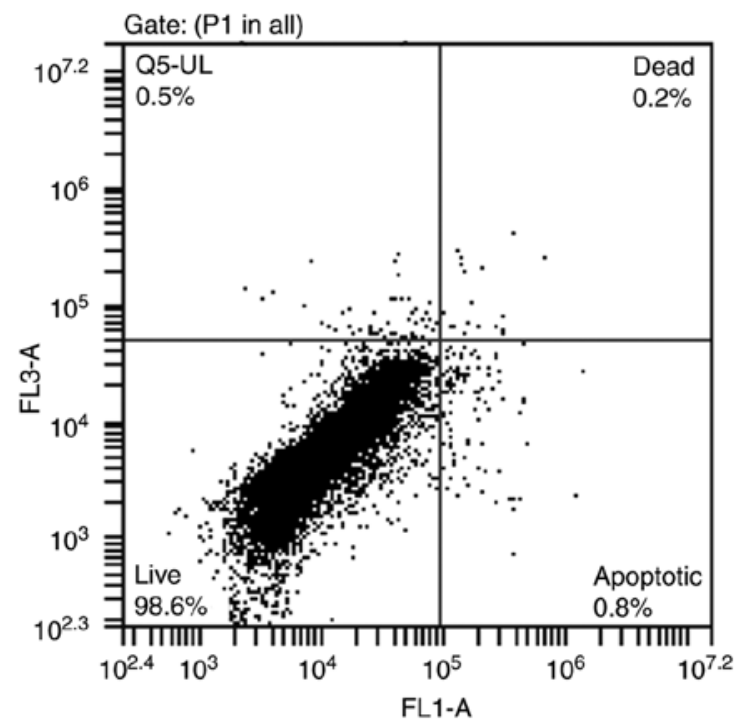

Control

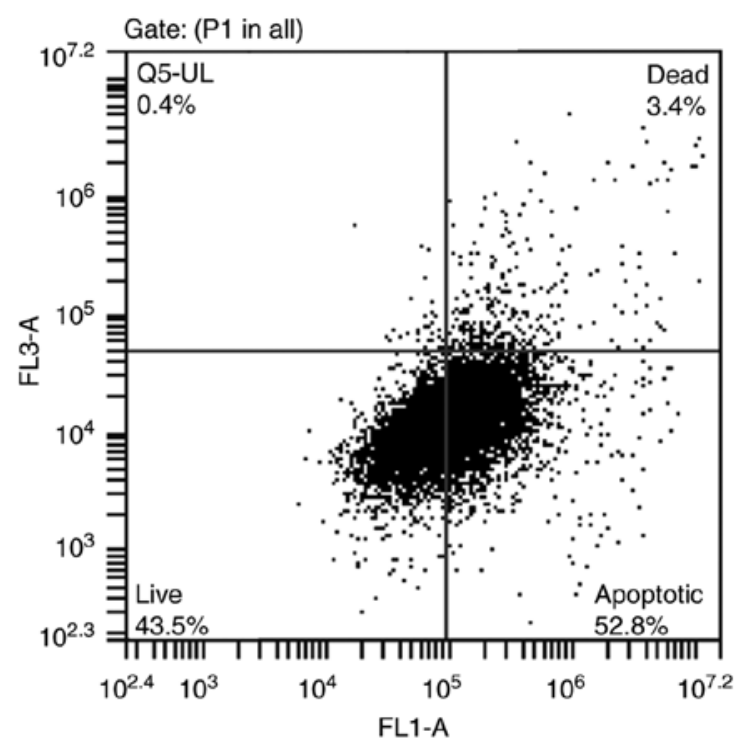

Polyphyllin VII+Wortmanin

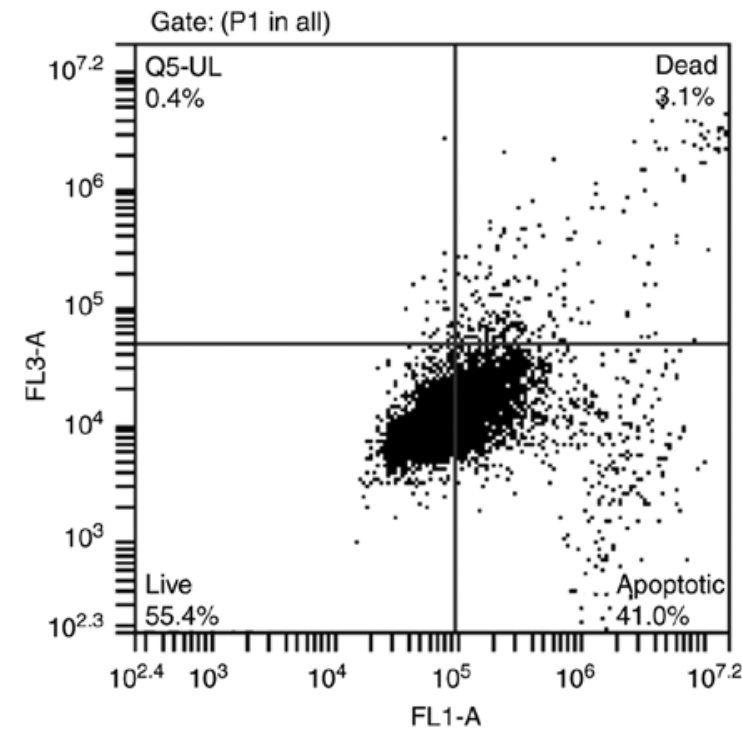

Polyphyllin VII $0.41 \mu \mathrm{M}$

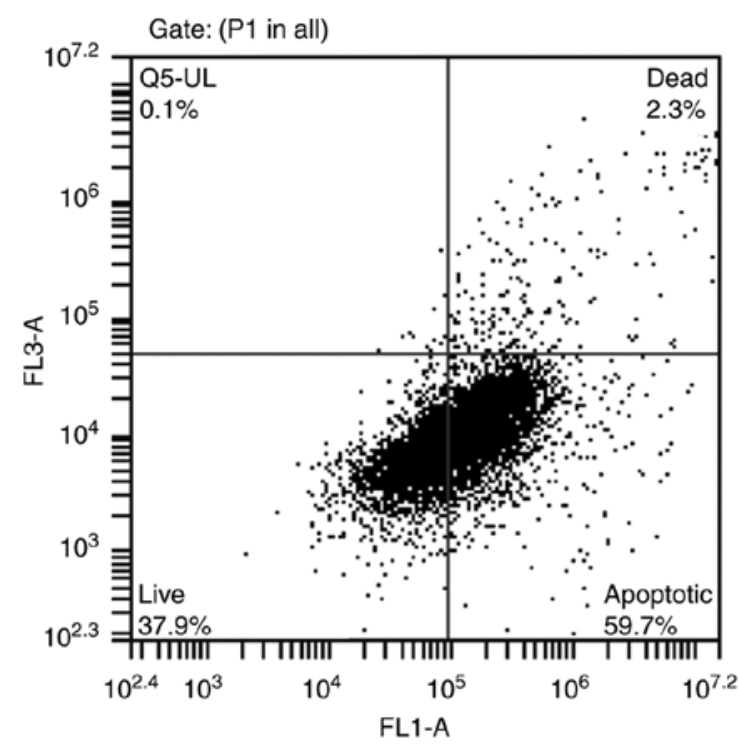

Polyphyllin VII+PDTC

Figure 3. Polyphyllin VII-induced apoptosis is associated with PI3K and NF- $\mathrm{kB}$. A549 cells were cultured with $0.41 \mu$ M Polyphyllin VII in the presence or absence of $2 \mu \mathrm{M}$ wortmannin or $30 \mu \mathrm{M}$ PDTC for $24 \mathrm{~h}$, then stained with Annexin V-FITC and propidium iodide. The apoptosis ratio was measured by flow cytometric analysis. Representative plots are shown. PDTC, pyrrolidine dithiocarbamate.

expression levels of apoptosis-related proteins in A549 cells were also examined by western blot analysis. Polyphyllin VII treatment induced significant changes in the expression levels of apoptosis-related proteins, including increased activation of cleaved pro-caspase-3 and PARP, and a downregulation of ICAD, which causes a release of caspase-activated DNase and triggers DNA fragmentation in nuclei (Fig. 5).

Next, the effects of the combination treatments were investigated in the protein expression levels of the A549 cells. Cleavage of pro-caspase-3 and PARP in Polyphyllin VII-treated A549 cells was further increased following cotreatment with wortmannin or PDTC (Fig. 5). In addition, the inhibitory effect of Polyphyllin VII on ICAD expression was further enhanced by wortmannin and PDTC (Fig. 5). Although no significant differences were observed in the ratios of $\mathrm{p}-\mathrm{PI} 3 \mathrm{~K} / \mathrm{PI} 3 \mathrm{~K}$ and p-Akt/Akt following Polyphyllin VII treatment, these
$\mathrm{p}-\mathrm{PI} 3 \mathrm{~K} / \mathrm{PI} 3 \mathrm{~K}$ and $\mathrm{p}$-Akt/Akt ratios were significantly suppressed by wortmannin pretreatment; however, no significant effect was observed by PDTC pre-treatment (Fig. 5). The $\mathrm{p}-\mathrm{NF}-\kappa \mathrm{B}$ p $65 / \mathrm{NF}-\kappa \mathrm{B}$ p65, ratio was significantly decreased by both PDTC and wortmannin pretreatments (Fig. 5). Similarly, the levels of nuclear p-NF- $\mathrm{B}$ p65 were significantly decreased by both the PDTC and wortmannin pretreatments, compared with the Polyphyllin VII treatment alone (Fig. 5). In summary, these data indicated that Polyphyllin VII induced apoptotic death in A549 cells via downregulation of the proteins in the $\mathrm{PI} 3 \mathrm{~K} / \mathrm{Akt}$ and $\mathrm{NF}-\kappa \mathrm{B}$ pathways.

\section{Discussion}

Our previous study demonstrated that $P$. polyphylla steroidal saponins induce apoptotic death in A549 cells (14). Polyphyllin 

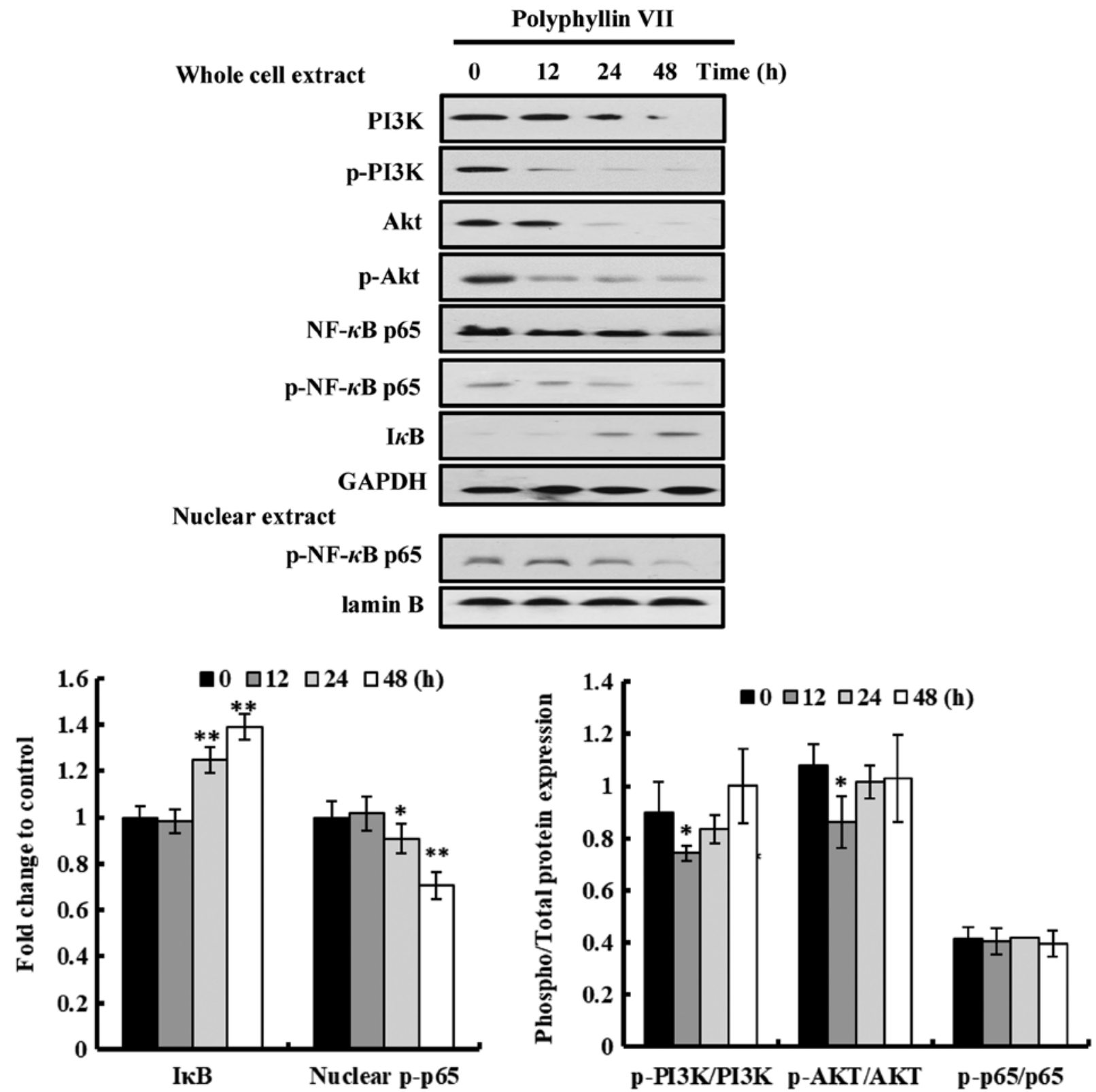

Figure 4. Polyphyllin VII affects the expression levels of proteins in the PI3K/Akt and NF-kB pathways. A549 cells were cultured with $0.41 \mu$ M Polyphyllin VII for $0,12,24$ and $48 \mathrm{~h}$, then evaluated by western blot analysis. GAPDH was used as a loading control for whole cell extract and lamin B was used as the loading control for nuclear extract. Densitometry results were expressed as average density relative to GAPDH or lamin B, or as a ratio of phosphorylated to total levels. Data are presented as mean \pm standard deviation of 3 independent experiments. ${ }^{*} \mathrm{P}<0.05$ and ${ }^{* * *} \mathrm{P}<0.01$ vs. control group. $\mathrm{p}-$, phosphorylated; I $\mathrm{B}$, nuclear factor of $\kappa$ light polypeptide gene enhancer in B-cells inhibitor.

VII, a type of steroidal saponin, was initially isolated from P. polyphylla. The present study demonstrated that Polyphyllin VII induced apoptosis in A549 human lung cancer cells via the PI3K/Akt and NF- $\kappa$ B pathways.

In total, $>50 \%$ of anticancer drugs are designed based on natural products. Numerous natural products have been reported to exert anticancer effects by inducing apoptosis of cancer cells (15). For example, Polyphyllin VII, a natural product from $P$. polyphylla, has been reported to exhibit anticancer effects (16). The present study identified that Polyphyllin VII was able to induce apoptotic death in A549 human lung cancer cells via downregulation of PI3K and Akt and inhibition of NF- $\mathrm{kB}$. A previous study reported that Polyphyllin VII induced autophagic cell death by activation of the JNK pathway and inhibition of the PI3K/Akt/mTOR pathway in human liver cancer HepG2 cells (16). Additionally, it has been suggested that Polyphyllin VII exerts anticancer effects by inducing cell cycle arrest and apoptosis in A549 cells; however, the underlying mechanism remains to be elucidated (17). Polyphyllin VII also induces apoptosis and autophagy via activation of ERK, Akt, p38 and JNK in oral cancer cells, which demonstrates that the biological effect of Polyphyllin VII is associated with Akt activation $(18,19)$. The present study revealed that the Polyphyllin VII-induced apoptotic cell death of A549 cells was associated with a downregulation of the PI3K/Akt pathway.

The PI3K/Akt signaling pathway is closely associated with programmed cell death, cell proliferation, migration 


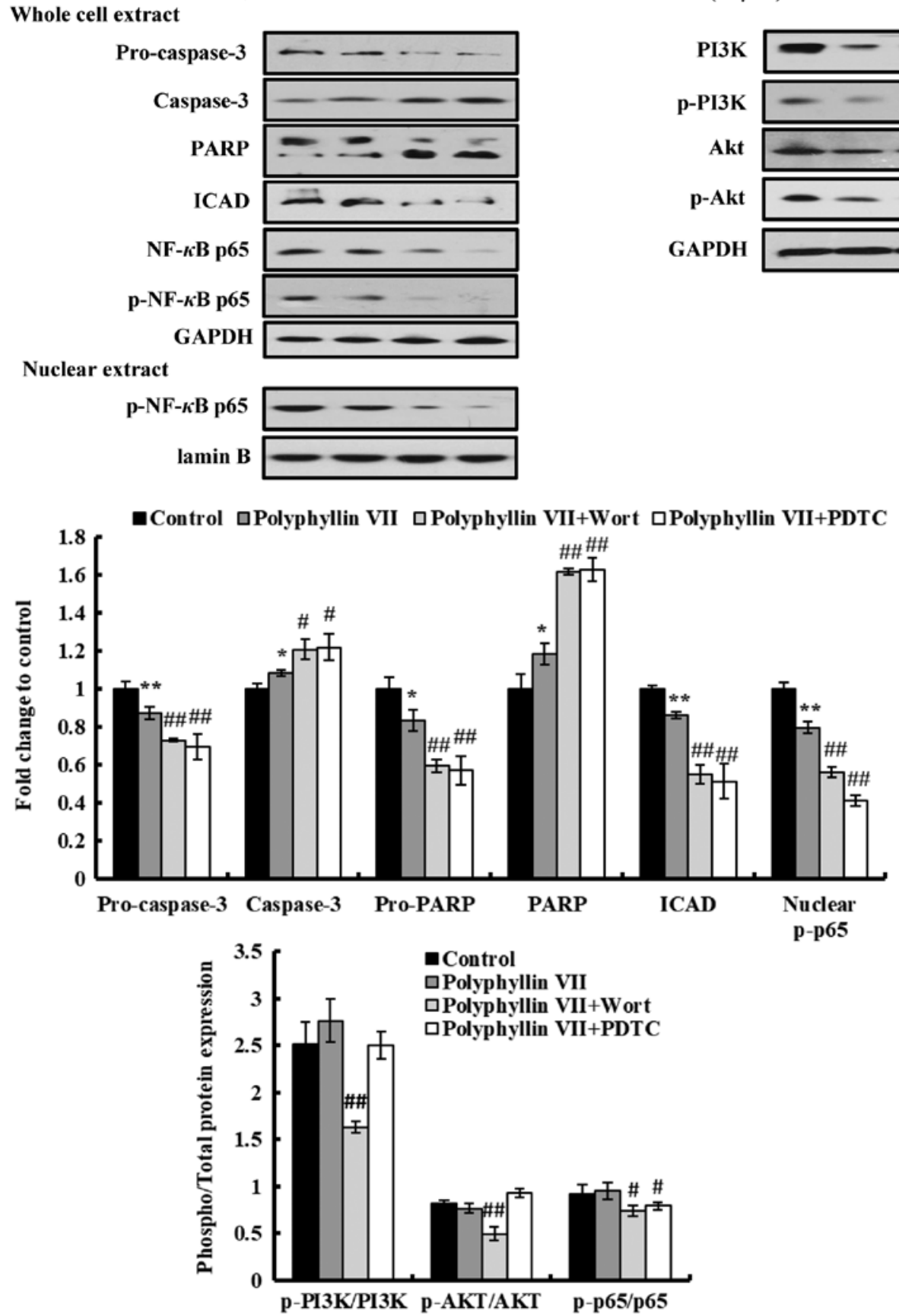

Figure 5. Polyphyllin VII induces apoptosis of A549 cells via the PI3K/Akt and NF-kB pathways. A549 cells were treated with $0.41 \mu$ M Polyphyllin VII in the presence or absence of wortmannin and PDTC for $24 \mathrm{~h}$. Protein expression levels were then evaluated by western blotting. GAPDH was used as a loading control for whole cell extract and lamin B was used as the loading control for nuclear extract. Densitometry results were expressed as average density relative to GAPDH or lamin B, or as a ratio of phosphorylated to total levels. Data are presented as mean \pm standard deviation of 3 independent experiments. ${ }^{*} \mathrm{P}<0.05$ and ${ }^{* *} \mathrm{P}<0.01$ vs. control group; ${ }^{\#} \mathrm{P}<0.05$ and ${ }^{\# \#} \mathrm{P}<0.01$ vs. Polyphyllin VII-treated group. PDTC, pyrrolidine dithiocarbamate; p-, phosphorylated; PARP, poly-(ADP-ribose) polymerase; ICAD, inhibitor of caspase-activated DNase.

and differentiation, and serves central roles in tumorigenesis and cell survival (20). The overexpression of PI3K and Akt in numerous types of human cancer is significantly associated with poor overall survival. Akt inhibits cell apoptosis and activates effector molecules, including NF- $\mathrm{KB}$. Furthermore, PI3K/Akt signaling affects the expression of $\mathrm{Bcl}-2$ protein, which is associated with the mitochondrial membrane potential and the mitochondrial apoptotic pathway $(21,22)$. In the present study, it was identified that in A549 cells, Polyphyllin VII reduced the expression levels of PI3K and Akt, causing a decrease in the mitochondrial membrane potential, and inducing apoptotic death.

Polyphyllin VII also exerts anti-inflammatory activities in vitro and in vivo, via a downregulation of the MAPK and 
NF- $\kappa \mathrm{B}$ pathways (23), which indicates that the effects of Polyphyllin VII may be associated with the NF- $\mathrm{B}$ pathway. The NF- $\kappa \mathrm{B}$ transcription factor family is extensively involved in numerous biological processes, including inflammation, immunity, cellular proliferation and the suppression of apoptosis $(24,25)$. Phosphorylation of the NF- $\kappa \mathrm{B}$ p65 subunit promotes transcriptional activity of $\mathrm{NF}-\kappa \mathrm{B}$, followed by a regulation of the release of pro-inflammatory cytokines (26). $\mathrm{NF}-\kappa \mathrm{B}$ p65 regulates Bcl-2 and Bcl-xl, which localize to the outer membrane of mitochondria, suppressing the expression of Bax and Bak. Bax and Bak facilitate a decrease of the mitochondrial membrane potential and the release of cytochrome c, which triggers apoptotic cell death $(22,27)$.

The current study identified that Polyphyllin VII-treatment inhibited the expression of proteins associated with PI3K/Akt signaling, which resulted in the suppression of $\mathrm{NF}-\kappa \mathrm{B}$ p65. Wortmannin, a PI3K inhibitor, combined with Polyphyllin VII, significantly enhanced the suppression of NF- $\kappa \mathrm{B}$ p65 and increased the apoptosis of A549 cells. Similarly, PDTC, a $\mathrm{NF}-\kappa \mathrm{B}$ inhibitor, enhanced the suppression of $\mathrm{NF}-\kappa \mathrm{B}$ p 65 and increased apoptosis; however, PDTC exhibited no prominent effects on PI3K/Akt signaling in Polyphyllin VII-treated A549 cells. These results demonstrated that Polyphyllin VII may be effective against lung cancer A549 cells. Of note, when the NCI-H460 and SK-MES-1 lung cancer cell lines were used in the present study, different mechanisms were obvious for the Polyphyllin VII treatment in the different cell lines (data not shown); therefore, the exact mechanism of Polyphyllin VII in lung cancer remains under research and will be further explored in future studies. Polyphyllin VII also exhibits its effects in combination with other drugs in research on cell lines. Polyphyllin VII has been reported to increase sensitization to gefitinib in gefitinib-resistant NSCLC cells via G1 phase arrest and modulation of the p21 signaling pathway (28). In addition, formosanin C and Polyphyllin VII have demonstrated a synergistic antitumor effect on lung cancer cells (29). These findings may provide a potential strategy to overcome drug resistance in NSCLC by using a combination of drugs with Polyphyllin VII.

In summary, it can be concluded that treatment with Polyphyllin VII was effective against lung cancer A549 cells via PI3K/Akt-mediated suppression of NF- $\mathrm{B}$ p65 activity, which resulted in mitochondrial dysfunction and apoptosis. In the future, with further understanding of its mechanism, Polyphyllin VII might serve as a potential candidate for the treatment of NSCLC, either alone or in combination with other compounds.

\section{Acknowledgements}

Not applicable.

\section{Funding}

The present study was supported by the National Natural Science Foundation of China (grant no. 81603265), the Innovative Talents Promotion Plan in Shaanxi Province (grant no. 2019KJXX-057), the Shaanxi Natural Science Basic Research Project (grant no. 2017JQ8042) and the foundation of Xi'an medical university (grant nos. 2017PT03 and 05041904).

\section{Availability of data and materials}

The datasets used and/or analyzed during the present study are available from the corresponding author on reasonable request.

\section{Authors' contributions}

$\mathrm{HH}$ conceived and designed the study, and also reviewed and edited the manuscript. CX performed experiments and wrote the paper. $\mathrm{LZ}$ performed data analysis. $\mathrm{KW}, \mathrm{MJ}$, YS and ZY performed experiments. All authors read and approved the final manuscript.

\section{Ethics approval and consent to participate}

Not applicable.

\section{Patient consent for publication}

Not applicable.

\section{Competing interests}

The authors declare that they have no competing interests.

\section{References}

1. Torre LA, Siegel RL and Jemal A: Lung Cancer Statistics. Adv Exp Med Biol 893: 1-19, 2016.

2. Siegel RL, Miller KD and Jemal A: Cancer statistics, 2018. CA Cancer J Clin 68: 7-30, 2018.

3. Rajasinghe LD, Pindiprolu RH and Gupta SV: Delta-tocotrienol inhibits non-small-cell lung cancer cell invasion via the inhibition of NF- $\kappa B$, $u$ PA activator, and MMP-9. Onco Targets Ther 11: 4301-4314, 2018.

4. Xia Y, Shen S and Verma IM: NF- $\kappa B$, an active player in human cancers. Cancer Immunol Res 2: 823-830, 2014.

5. Rasheduzzaman M, Jeong JK and Park SY: Resveratrol sensitizes lung cancer cell to TRAIL by p53 independent and suppression of Akt/NF- $\kappa B$ signaling. Life Sci 208: 208-220, 2018.

6. Jiang J, Xu Y, Ren H, Wudu M, Wang Q, Song X, Su H, Jiang X, Jiang $L$ and Qiu X: MKRN2 inhibits migration and invasion of non-small-cell lung cancer by negatively regulating the PI3K/Akt pathway. J Exp Clin Cancer Res 37: 189, 2018.

7. Newman DJ and Cragg GM: Natural products as sources of new drugs from 1981 to 2014. J Nat Prod 79: 629-661, 2016.

8. Tu X, Deng Y, Chen J, Hu Q, He C, Jordan JB and Zhong S: Screening study on the anti-angiogenic effects of traditional Chinese medicine-part I: Heat-clearing and detoxicating TCM. J Ethnopharmacol 194: 280-287, 2016.

9. Guo J, Gao Y, Wang Y, Liu WJ, Zhou J and Wang Z: Application of herbal medicines with heat-clearing property to antimicroinflammation in the treatment of diabetic kidney disease. Evid Based Complement Alternat Med 2019: 6174350, 2019.

10. Committee CP: Pharmacopoeia of The People's Republic of China China Medical Science Press: Beijing, 2015.

11. Yin X, Qu C, Li Z, Zhai Y, Cao S, Lin L, Feng L, Yan L and Ni J: Simultaneous determination and pharmacokinetic study of polyphyllin I, polyphyllin II, polyphyllin VI and polyphyllin VII in beagle dog plasma after oral administration of Rhizoma Paridis extracts by LC-MS-MS. Biomed Chromatogr 27: 343-348, 2013.

12. He H, Zang LH, Feng YS, Chen LX, Kang N, Tashiro S, Onodera S, Qiu F and Ikejima T: Physalin A induces apoptosis via p53-Noxa-mediated ROS generation, and autophagy plays a protective role against apoptosis through $\mathrm{p} 38-\mathrm{NF}-\kappa \mathrm{B}$ survival pathway in A375-S2 cells. J Ethnopharmacol 148: 544-555, 2013.

13. Liu W, Otkur W, Li L, Wang Q, He H, Ye Y, Zhang Y, Hayashi T, Tashiro S, Onodera S and Ikejima T: Autophagy induced by silibinin protects human epidermoid carcinoma A431 cells from UVB-induced apoptosis. J Photochem Photobiol B 123: 23-31, 2013. 
14. He H, Sun YP, Zheng L and Yue ZG: Steroidal saponins from Paris polyphylla induce apoptotic cell death and autophagy in A549 human lung cancer cells. Asian Pac J Cancer Prev 16: 1169-1173, 2015.

15. Wang Y,Zhong J, Bai J, Tong R, An F, Jiao P, He L, Zeng D, Long E, Yan J, et al: The application of natural products in cancer therapy by targeting apoptosis pathways. Curr Drug Metab 19: 739-749, 2018.

16. Zhang C, Jia X, Wang K, Bao J, Li P, Chen M, Wan JB, Su H, Mei Z and He C: Polyphyllin VII induces an autophagic cell death by activation of the JNK pathway and inhibition of PI3K/AKT/mTOR pathway in HepG2 cells. PLoS One 11: e0147405, 2016.

17. Lin Z, Liu Y, Li F, Wu J, Zhang G, Wang Y, Lu L and Liu Z: Anti-lung cancer effects of polyphyllin VI and VII potentially correlate with apoptosis in vitro and in vivo. Phytother Res 29: $1568-1576,2015$.

18. Chen JC, Hsieh MJ, Chen CJ, Lin JT, Lo YS, Chuang YC, Chien SY and Chen MK: Polyphyllin G induce apoptosis and autophagy in human nasopharyngeal cancer cells by modulation of AKT and mitogen-activated protein kinase pathways in vitro and in vivo. Oncotarget 7: 70276-70289, 2016.

19. Hsieh MJ, Chien SY, Lin JT, Yang SF and Chen MK: Polyphyllin $\mathrm{G}$ induces apoptosis and autophagy cell death in human oral cancer cells. Phytomedicine 23: 1545-1554, 2016.

20. Sarris EG, Saif MW and Syrigos KN: The biological role of PI3K pathway in lung cancer. Pharmaceuticals (Basel) 5: 1236-1264,2012

21. Ozes ON, Mayo LD, Gustin JA, Pfeffer SR, Pfeffer LM and Donner DB: NF-kappaB activation by tumour necrosis factor requires the Akt serine-threonine kinase. Nature 401: 82-85, 1999.

22. Catz SD and Johnson JL: Transcriptional regulation of bcl-2 by nuclear factor kappa B and its significance in prostate cancer. Oncogene 20: 7342-7351, 2001.
23. Zhang C, Li C, Jia X, Wang K, Tu Y, Wang R, Liu K, Lu T and $\mathrm{He} \mathrm{C}$ : In vitro and in vivo anti-inflammatory effects of polyphyllin VII through downregulating MAPK and NF- $\mathrm{B}$ pathways. Molecules 24: E875, 2019.

24. Panday A, Inda ME, Bagam P, Sahoo MK, Osorio D and Batra S: Transcription Factor NF- $\mathrm{BB}$ : An Update on Intervention Strategies. Arch Immunol Ther Exp (Warsz) 64: 463-483, 2016.

25. Schuliga M: NF-kappaB signaling in chronic inflammatory airway disease. Biomolecules 5: 1266-1283, 2015.

26. Chen T, Wang R, Jiang W, Wang H, Xu A, Lu G, Ren Y, Xu Y, Song Y, Yong S, et al: Protective effect of astragaloside IV against paraquat-induced lung injury in mice by suppressing Rho signaling. Inflammation 39: 483-492, 2016.

27. Zamora M, Meroño C, Viñas O and Mampel T: Recruitment of NF-kappaB into mitochondria is involved in adenine nucleotide translocase 1 (ANT1)-induced apoptosis. J Biol Chem 279: 38415-38423, 2004.

28. Wang H, Fei Z and Jiang H: Polyphyllin VII increases sensitivity to gefitinib by modulating the elevation of P21 in acquired gefitinib resistant non-small cell lung cancer. J Pharmacol Sci 134: 190-196, 2017.

29. Cui J, Man S, Cui N, Yang L, Guo Q, Ma L and Gao W: The synergistic anticancer effect of formosanin $\mathrm{C}$ and polyphyllin VII based on caspase-mediated cleavage of Beclin1 inhibiting autophagy and promoting apoptosis. Cell Prolif 52: e12520, 2019.

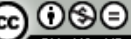

This work is licensed under a Creative Commons Attribution-NonCommercial-NoDerivatives 4.0 International (CC BY-NC-ND 4.0) License. 